\title{
熱赤外リモートセンシングによる水稲の群落表面温度の 観測並びに葉温と葉色の関係
}

\author{
脇 山 恭 行 \\ (中央農業総合研究センター耕地環境部)
}

\section{Infrared Remote Sensing for Canopy Temperature in Paddy Field and Relationship between Leaf Temperature and Leaf Color}

\author{
Yasuyuki WAKIYAMA \\ (National Agricultural Research Center, Tsukuba, 305-8666 Japan)
}

\begin{abstract}
Infrared remote sensing is used for crop monitoring, for example evaluation of water stress, detection of infected crops and estimation of transpiration and photosynthetic rates. This study was conducted to show another application of remote sensing information. The relationship between rice leaf temperature and chlorophyll content in the leaf blade was investigated by using thermography during the ripening period. The canopy of a rice community fertilized by top dressing was cooler than that not fertilized in a 1999 field experiment. In an experiment using thermocouples to measure leaf temperature, a rice leaf with high chlorophyll content was also cooler than that with a low chlorophyll content. Transpiration resistance and transpiration rate were measured with a porometer. Transpiration rate was higher with increasing chlorophyll content in the leaf blade. Stomatal aperture is related to chlorophyll content in the leaf blade. High degree of stomatal aperture is caused by high chlorophyll content in the leaf blade. As degree of stomatal aperture increases, transpiration rate increases. Therefore the rice leaf got cooler with increasing chlorophyll content in leaf blade. Paddy rice communities with different chlorophyll contents were provided with fertilization of different nitrogen levels on basal and top dressing in a 2000 field experiment. Canopy temperature of the rice community with high chlorophyll content was $0.85^{\circ} \mathrm{C}$ cooler than that of the rice community with low chlorophyll content. Results of this study revealed that infrared remote sensing could detect difference in chlorophyll contents in rice communities and could be used in fertilizer management in paddy fields.
\end{abstract}

Key words: Canopy temperature, Chlorophyll content, Infrared remote sensing, Paddy rice, Transpiration resistance.

キーワード : クロロフィル濃度, 群落表面温度, 蒸散抵抗, 水稲, 熱赤外リモートセンシング

\section{1.はじめに}

作物の生理的な光合成に関する研究については, 気孔 開度と光合成速度, 気孔開度之蒸散速度の関係について 数種類の作物を対象に調べられ，いくつかの報告がみら れる（たとえば Ishihara et al., 1972）。一般に，気孔開

2000 年 8 月 24 日, 全国大会にて発表

2001 年 11 月 16 日, 関東支部例会にて発表

2001 年 12 月 10 日 受付, 2002 年 6 月 28 受理
度が大きいと $\mathrm{CO}_{2}$ の気孔内への取り込みが進み, 光合 成速度も大きい。同時に蒸散速度屯大きいため, 蒸散速 度と光合成速度との間には密接な関係がみられる (Inoue, 1987)。一方，葉加らの蒸散は潜熱による熱の 移動を伴うため葉温にも影響を与える。同じ環境下にお かれた葉の温度は蒸散速度が小さいと上昇し, 蒸散速度 が大きいと低下する。このように, 蒸散速度の変化に よって, 葉温に変化が生じる。この現象を熱赤外りモー トセンシングによってとらえ, 作物モニタリングへの応 
用を試みた報告がみられる。たとえば，Jackson et al. （1981） は土壌水分の低下により起こる作物の水分ス卜 レスの程度を, 放射温度計で測定した群落表面温度を用 いて指標化した。病害の被害予測については, Pinter et al.（1979）は放射温度計を用いて，テンサイ，ワタの土 壌伝染病を対象に視覚的に病徵をとらえられない罹病個 体を検出できることを, Yamamoto et al. (1995) 屯, サーモグラフィを用いて，水稲群落内のいもち病の発生 箇所を早期に検出できることを報告している。Inoue （1987）は，リモートセンシング手法により推定した蒸 散速度と飽差を用いることにより, 光合成速度の算出が 可能であることを述べている。Homma et al. (1999) は，サーモグラフィで測定した群落表面温度を用いて， 高温・高 $\mathrm{CO}_{2}$ 環境下におかれた水稲の蒸散速度を推定 した。また, Miyashita et al.（1999）は放射温度計を用 いて, 世界各地で栽培されている大麦の葉温を測定し, 原産地による蒸散特性の差異を報告している。

今回，これらの報告のほかに熱赤外りモートセンシン グ情報の利用場面を検討するために，水稲を対象に葉色 を变化させた場合の群落表面温度抢よび葉温の観測を 行った。その結果, いくつかの知見が得られたので報告 する。

\section{2. 材料および方法}

\section{1 ポットでの栽培実験}

水稲の登熟期に扔ける葉色の変化を調べるために, ポット実験を行った。品種にはキヌヒカリを用い, 1998 年 4 月 25 日に播種し, 箱育苗により育苗した。葉齢が 3.5 に達した苗を 5 月 25 日に, 2,000 分の 1 ワグネル ポットに, 1 株 1 本とし 2 株移植した。基肥には, 化成 肥料（窒素，リン酸，カリの含有率はいずれあ 14\%）を 用い，ポット当たり $6.4 \mathrm{~g}$ 施用した。反復は 4 ポットと し, 追肥は行わなかった。出穂期は 8 月 21 日であった。
葉色の測定は葉緑素計（ミノル夕, SPAD 502）を用い て, 毎回同じ茎の展開した上位 3 葉を対象に, 出穂 1 週 前から登熟後期まで, 1 週毎に 3 葉の平均 SPAD 值を 求めた。収穫は 9 月 30 日に 1 穂ごとに行い, 穂につい た籾をすべて取り粐数と粐の重さを計測し，それぞれ 1 穂籾数, 1 穂籾重とした。

\section{2 固場での栽培実験}

サーモグラフィーによる群落表面温度および熱電対に よる葉温を測定するため, 中央農業総合研究センター谷 和原水田圃場（茨城県谷和原村）において栽培実験を 行った。実験は, 予備的である 1999 年と 2000 年の 2 力 年行った。いずれの年度む, 処理区間の稲体中のクロロ フィル濃度に差がでるように施肥量を変え栽培した。 1999 年は, 供試品種にコシヒカリを用い，4 月 26 日に 播種し，箱育苗により育苗した。移植には葉齢が扰よそ 3.5 に達した苗を用い, 5 月 20 日に 1 株 3 本とし, 手植 えにより行った。栽植密度は株間 $15 \mathrm{~cm}$, 畧間 $30 \mathrm{~cm}$, 各処理区の面積は $50 \mathrm{~m}^{2}$ であった。基肥には化成肥料 （窒素，リン酸，カリの含有率はいずれす $14 \%$ ）を用い, 施用量を 3 段階とし，さらにそれぞれの処理区に追肥区 と無追肥区を設けた。追肥にあ基肥と同じく化成肥料 （窒素，カリの含有率はいずれも 17\%）を用いた。2000 年も 1999 年と同じ方法で育苗, 移植を行った。ただし, 供試品種には日本晴を用い, 施肥量を 1999 年に比べて 大幅に増やし, 処理区間の生育量, クロロフィル濃度差 が明瞭に現れるように栽培した。Table 1 に各処理区の 施肥量 (成分量), Table 2 には耕種日程を示した。

2000 年固場実験での生育調査は, 生育初期より登熟 期まで， 2 週ごとに行った。調査は各処理区より平均的 な株を 5 株掘り上げ, 葉面積, 生体重, 乾物重の項目に ついて調査した。葉面積は, 各区から 1 株を選び葉面積 計（林電工，面積計 AAM-9 型）を用い測定した。同時 に葉の生体重を計り, 生体重当たりの葉面積を計算し

Table 1. Fertilizer application for field experiment.

\begin{tabular}{|c|c|c|c|c|c|c|}
\hline \multirow{2}{*}{ Year } & \multirow{2}{*}{$\begin{array}{c}\text { Experimental } \\
\text { treatment }\end{array}$} & \multicolumn{3}{|c|}{ Basal dressing $\left(\mathrm{kg} 10 \mathrm{a}^{-1}\right)$} & \multicolumn{2}{|c|}{ Top dressing $\left(\mathrm{kg} 10 \mathrm{a}^{-1}\right)$} \\
\hline & & Nitrogen & Phosphorus & Potassium & Nitrogen & Potassium \\
\hline \multirow[t]{6}{*}{1999} & N4. 5-1 & 4.5 & 4.5 & 4.5 & 2.3 & 2.3 \\
\hline & $\mathrm{N} 4.5-0$ & 4.5 & 4.5 & 4.5 & 0.0 & 0.0 \\
\hline & N3-1 & 3.0 & 3.0 & 3.0 & 1.5 & 1.5 \\
\hline & $\mathrm{N} 3-0$ & 3.0 & 3.0 & 3.0 & 0.0 & 0.0 \\
\hline & $\mathrm{N} 1.5^{-1}$ & 1.5 & 1.5 & 1.5 & 0.8 & 0.8 \\
\hline & $\mathrm{N} 1.5-0$ & 1.5 & 1.5 & 1.5 & 0.0 & 0.0 \\
\hline \multirow[t]{4}{*}{2000,2001} & N13 & 13.0 & 13.0 & 13.0 & 5.6 & 5.6 \\
\hline & N9 & 9.0 & 9.0 & 9.0 & 3.9 & 3.9 \\
\hline & N4 & 4.0 & 4.0 & 4.0 & 1.7 & 1.7 \\
\hline & No & 0.0 & 0.0 & 0.0 & 0.0 & 0.0 \\
\hline
\end{tabular}


た。ほかの株は生体重のみ計り，この葉面積と生体重の 関係から, 葉面積を推定した。各処理区の乾物重, 葉面 積は 5 株の值を平均し求めた。クロロフィル濃度の推定 には，葉緑素計を用い，各処理区の 10 株を対象に各株 より 1 本の主程を選び, 展開した上位 3 葉の SPAD 值 を測定した。次に, 測定した各葉の SPAD 值を平均し, 後述する SPAD 值加ら葉身中のクロロフィル濃度を推 定する検量線を用いて, 上位 3 葉のクロロフィル濃度を 推定した。収量調查は, 坪刈りによる粐収量と各処理区 より掘り上げた 10 株について穂数， 1 穂粐数等の収量 構成要素を調查した。

サーモグラフィー（日本アビオニクス，TVS-2000 LW）による群落表面温度の測定は, 出穂直後から登熟 後期にかけて，1 週おきに晴天日の午前中に行った。測 定方法は, 運搬車に検出器を載せ, 実験水田に沿った道 路上を移動しながら各処理区を測定した。検出器は, 水 田面からの高さがおよそ $2 \mathrm{~m}$, 伏角は $15^{\circ}$ で, 群落表面 を俯瞰できるように調節した。サーモグラフィーの視野 角は垂直方向 $10^{\circ}$, 水平方向 $15^{\circ}$, 射出率は 1.00 （Inoue, 1986）であった。群落表面温度は, 測定した画 像から群落表面部分の温度を平均し求めた。

葉温の測定には, 直径 $0.1 \mathrm{~mm}$ の銅一コンスタンタン 熱電対を用いた。熱電対の装着方法は, 直達日射が熱電 対の感部にあたらないように，向軸面が南を向いている 止葉を選び，その背軸面に葉脈をさけて熱電対の感部を あて医療用テープ (不織布)で固定した。葉温測定には, 1999 年は各処理区から 2 5 枚の止葉を, 2000 年は 6 10 枚の止葉を選んだ。葉温の測定は, 1999 年は 8 月 21 日から 9 月 7 日まで, 2000 年は, 8 月 14 日から 9 月 20 日まで行った。熱電対を装着した止葉については, 1 週每に葉緑素計で葉色を測った。収穫時には, 葉温を 測った止葉と同じ茎の穂を切り取り， 1 穂籾数， 1 穂粐 重を求めた。

サーモグラフィーによる画像データおよび熱電対によ る葉温デー夕の解析の際, 必要となる気象デー夕を得る ために, 気象観測を行った。1999年は, 8 月 21 日から
9 月 7 日まで, 水田上に乾球・湿球温度計（高度 $1.5 \mathrm{~m}$ ) を設置し，気温と湿度を観測した。観測值は，データロ ガーに 10 分間平均値で記録した。全天日射量, 風向・ 風速デー夕は, 谷和原水田圃場内で観測している気象 デー夕を用いた。なお，風向・風速の観測高度は $6 \mathrm{~m}$ で あった。2000年は, 8 月 14 日から 9 月 20 日まで, 水田 上に乾球・湿球温度計 (高度 $1.5 \mathrm{~m}$ ), 全天日射計, 風 向・風速計（高度 $2 \mathrm{~m}$ ）を設置し観測を行った。

また，ポロメー夕（Li-cor, LI-1600）を用い, 蒸散抵 抗, 蒸散速度の測定を行った。測定は 2001 年に, 出穂 2 週前より登熟後期にかけ 1 週掞きに, 晴天日と曇天日の 10: 00〜13:00に行った。同時に蒸散抵抗, 蒸散速度を 測定した葉の葉色も葉緑素計で測定した。2001 年も供 試品種, 施肥量など 2000 年と全く同じ方法で栽培し た。施肥量および耕種日程をそれぞれ Table 1, Table 2 に示した。

葉身中のクロロフィル濃度の測定については, まず各 処理区より展開した上位 4 葉の葉をサンプリングし, 葉 緑素計で葉色を測定した。次に, 測定した葉を切り刻み, $80 \%$ アセトン $20 \mathrm{ml}$ 中に浸し, 冷暗所に 48 時間安置 し, クロロフィルを抽出した。その後, $645 \mathrm{~nm}, 663 \mathrm{~nm}$ の波長帯の吸光度を測定し, Arnon 法 (Arnon, 1949) により抽出液中のクロロフィル濃度を定量した。この作 業は, 2000 年圃場実験時に生育初期加ら登熟期まで 2 週ごとに行い，定量された葉身中のクロロフィル濃度と SPAD 值との関係をプロットし, SPAD 值から葉身中 のクロロフィル濃度を推定するための検量線を得た。

\section{3. 結果および考察}

\section{1 サーモグラフィーによる追肥区と無追肥区の群} 落表面温度の測定

1999 年圃場実験において, 出穂期にサーモグラ フィーを用いて測定した群落表面温度を Table 3 に示 した。測定は，8月 9日 10: 30 10: 55 に行った。基肥 量が同じで追肥を行った N4.5-1 区と追肥を行わなかっ

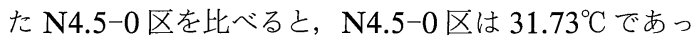

Table 2. Cultivation practice for field experiment.

\begin{tabular}{|c|c|c|c|c|c|c|}
\hline Year & Cultivar & Seeding & Transplanting & $\begin{array}{l}\text { Fertilization } \\
\text { of topdressing }\end{array}$ & Heading & Harvest \\
\hline 1999 & Koshihikari & $\begin{array}{c}26 \text { Apr. } \\
\text { (116) }\end{array}$ & $\begin{array}{c}20 \text { May } \\
(140)\end{array}$ & $\begin{array}{l}\text { 17 Jul. } \\
\text { (198) }\end{array}$ & $\begin{array}{l}8 \text { Aug. } \\
(220)\end{array}$ & $\begin{array}{c}20 \text { Sep. } \\
(263)\end{array}$ \\
\hline 2000 & Nihondare & $\begin{array}{l}27 \text { Apr. } \\
\text { (117) }\end{array}$ & $\begin{array}{l}25 \text { May } \\
(145)\end{array}$ & $\begin{array}{l}20 \mathrm{Jul} . \\
\text { (201) }\end{array}$ & $\begin{array}{l}12 \text { Aug. } \\
\text { (224) }\end{array}$ & $\begin{array}{c}25 \text { Sep. } \\
(268)\end{array}$ \\
\hline 2001 & Nihondare & $\begin{array}{l}25 \text { Apr. } \\
\text { (115) }\end{array}$ & $\begin{array}{l}23 \text { May } \\
\text { (143) }\end{array}$ & $\begin{array}{l}16 \mathrm{Jul} . \\
\text { (197) }\end{array}$ & $\begin{array}{l}18 \text { Aug. } \\
\text { (230) }\end{array}$ & $\begin{array}{l}4 \text { Oct. } \\
(277)\end{array}$ \\
\hline
\end{tabular}

Figures in parentheses are day of year. 
Table 3. Canopy temperature of paddy rice community.

\begin{tabular}{cc}
\hline Experimental treatment & $\begin{array}{c}\text { Canopy temperature } \\
\left({ }^{\circ} \mathrm{C}\right)\end{array}$ \\
\hline $\mathrm{N} 4.5-1$ & $30.91 \pm 0.34$ \\
$\mathrm{~N} 4.5-0$ & $31.73 \pm 0.34$ \\
\hline $\mathrm{N} 3-1$ & $30.72 \pm 0.34$ \\
$\mathrm{~N} 3-0$ & $31.33 \pm 0.43$ \\
\hline $\mathrm{N} 1.5-1$ & $30.45 \pm 0.39$ \\
$\mathrm{~N} 1.5-0$ & $30.79 \pm 0.34$ \\
\hline
\end{tabular}

Measurement was conducted from $10: 30$ to $10: 55$ on 9 August in 1999. Meteorological conditions are as follows. Air temperature was $32.5^{\circ} \mathrm{C}$. Relative humidity was 55\%. Solar radiation was $820 \mathrm{Wm}^{-2}$. Wind speed was $3.6 \mathrm{~ms}^{-1}$ (height $6 \mathrm{~m}$ ). Figures are the mean \pm standard deviation.

たのに対し， N4.5-1 は $30.91^{\circ} \mathrm{C}$ と， $0.82^{\circ} \mathrm{C} \mathrm{N} 4.5-1$ 区 の表面温度が低かった。N3-1 区と N3-0 区を比べると 0.61 ${ }^{\circ} \mathrm{C}$ N3-1 区が低く, N1.5-1 区と N1.5-0 区であ N 1.5-1 区が $0.34^{\circ} \mathrm{C} \mathrm{N} 1.5-0$ 区に比べ低かった。このよう にいずれの処理区でむ追肥区は無追肥区に比べて群落表 面温度が低かった。肉眼による観察では, 追肥区と無追 肥区の葉色を比べると, 明らかに追肥区で葉色が濃かっ た。

\section{2 葉温と気温の差と SPAD 值， 1 穂籾重の関係}

次に，1999 年圃場実験の各処理区の止葉に熱電対を 装着し葉温を測定した結果を Fig. 1 に示した。葉温 デー夕は 8 月 21 日 12:37 12: 47, 葉緑素計で測った SPAD 值は 8 月 23 日に測定されたものである。葉温と 気温の差 (以下, 葉気温差) と SPAD 值の関係は,

SPAD 值が低い，すなわちクロロフィル濃度が低いほ ぞ葉気温差はプラスでその差は大きいが，SPAD 值が 高いほど葉気温差はマイナスで葉温は気温に比べ低かっ た。相関をみると -0.77 之高い相関係数であった。熱電 対による葉温の測定においてあ, サーモグラフィーを用 いた測定と同様に，SPAD 值が高いほど葉温は低いこ とが確かめられた。また，追肥区と無追肥区から採取し た穂について， 1 穂籾重と Fig. 1 と同じく 8 月 21 日 12: 37〜 12: 47 に測定した葉気温差との関係をみたと ころ, 相関は低いが葉気温差がマイナスで葉温が気温に 比べて低いほど, 1 穂籾重が大きい傾向がみられた (Fig. 2)。追肥区だけから採取した穂についてみると，1 穂籾重と葉気温差の関係が明瞭に表れた（Fig. 2)。Fig. 3 には, 1998 年ポット実験での出穂直前の 8 月 18 日に 測定した上位 3 葉の平均 SPAD 值と 1 穂粐数の関係 (Fig. $3 \mathrm{~A})$, SPAD 值と 1 穂籾重との関係（Fig. 3 B）

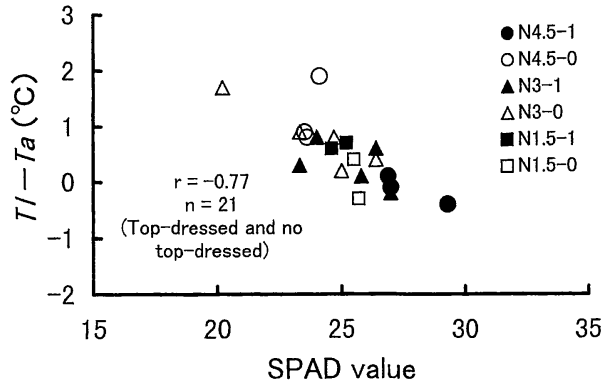

Fig. 1. Relationship between Leaf temperature and air temperature difference $(T l-T a)$ and SPAD value from $12: 37$ to $12: 47$ on 21 August in 1999. Meteorological conditions are as follows. Air temperature was $31.0^{\circ} \mathrm{C}$. Relative humidity was $51 \%$. Solar radiation was 864 $\mathrm{Wm}^{-2}$. Wind speed was $2.5 \mathrm{~ms}^{-1}$ (height $2 \mathrm{~m}$ ).

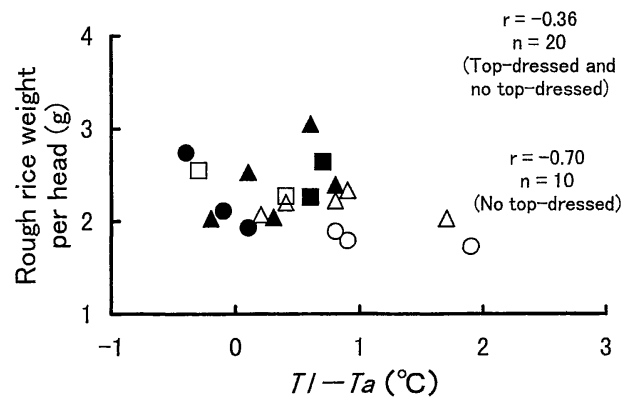

Fig. 2. Relationship between Leaf temperature and air temperature difference $(T l-T a)$ and rough rice weight per head. Symbols are the same as in Fig. 1.

を示した。1 穂籾数は SPAD 值が高いほど粐数が多く, 1 穂粐重は SPAD 值が高いほど粐重が大きかった。 Kumura（1956）は，出穗 7 日から 28 日前に抢ける葉 身中の平均窒素濃度が高いほど， 1 穂穎花数が多かった ことを報告している。Wada and Matsushima（1962） あ同一品種, 同一移植期の試験区内では, 出穂期の葉身 中の窒素濃度と 1 株当たりの粐数との間に高い相関が みられたことを述べている。ポット実験での結果は, こ れらの報告と一致した。このことから, 固場実験におい て葉気温差がマイナスで, 葉温が気温より低い穂で 1 穗 粐重が大きかったのは, 葉身中の窒素濃度が高かったた めに穎花分化数が増加し， 1 穂粐数が多くなり 1 穂籾重 が大きかったもの之考えられた。 

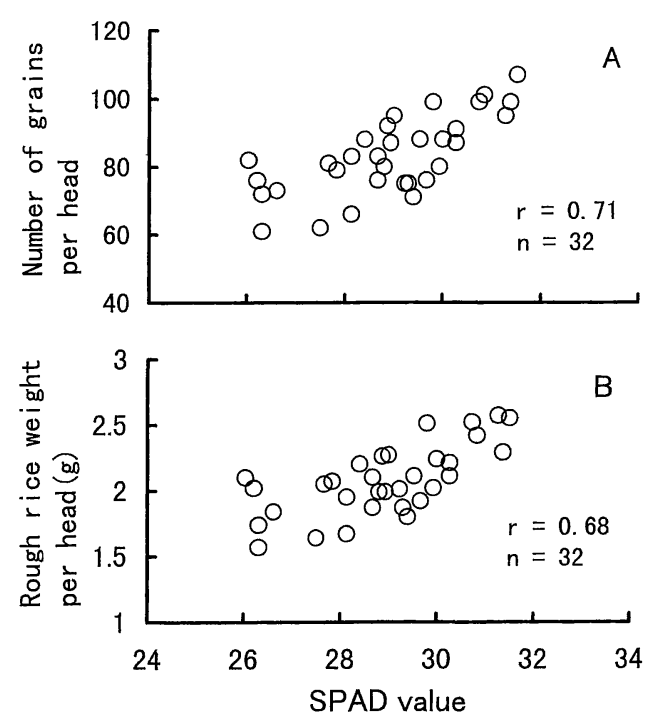

Fig. 3. Relationship between SPAD value and the number of grains per head (A), and relationship between SPAD value and rough rice weight per head (B).

\section{3 蒸散抵抗，蒸散速度と SPAD 值の関係}

サーモグラフィーによる追肥区，無追肥区間の群落表 面温度差, SPAD 值の異なる止葉間の葉気温差の違い は, 葉面上の気孔密度, 気孔開度の差異によって蒸散速 度に差が生じ，葉温に影響を及ぼしたためと考えられ た。そこで, ポロメータを用いて出穂 2 週前の上位展開 第 1 葉の蒸散抵抗，蒸散速度を測定し，その結果を Fig. 4 に示した。測定デー夕は，2001 年 8 月 3 日 11:20 12: 20 に得られたあのである。SPAD 值と蒸散抵抗の 関係は SPAD 值が高いほど，蒸散抵抗は小さかった (Fig. 4A)。SPAD 值と蒸散速度の関係は, SPAD 值が 高いほど蒸散速度が大きく，両者の間には高い相関がみ られた (Fig. 4B)。この結果より, SPAD 值の高い葉ほ ぞ葉温が低かったのは，蒸散が盛んであったため，潜熱 が奪われ葉温が低かったあのと考えられた。

Ishihara et al.（1978）は, 葉身中の窒素濃度と気孔開 度の関係について調べ，葉身中の窒素濃度が高いほど 気孔開度が大きいことを報告している。Tsuno et al. （1991）む，葉色板（富士葉色カラースケール）を用いて 葉色示度と気孔開度との関係を調べ，同様に葉色示度の 高い葉（クロロフィル濃度の高い葉）で気孔開度の大き いことを述べている。今回, 葉身中のクロロフィル濃度 之葉面の気孔密度, 気孔開度の関係について調べていな いが，気孔開度に対して，葉身中のクロロフィル濃度が影 響を及ぼしたことも原因の 1 つではないかと考えた。そ
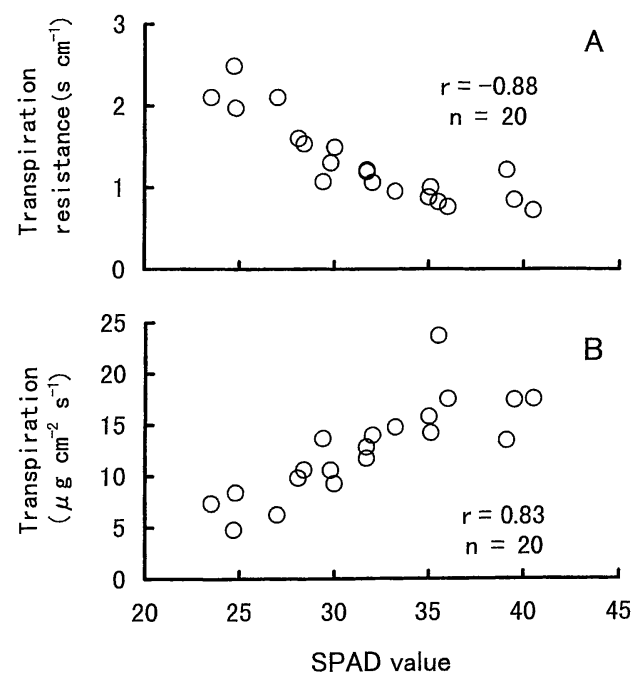

Fig. 4. Relationship between SPAD value and transpiration resistance (A), and relationship between SPAD value and transpiration (B) from $11: 20$ to $12: 20$ on 3 August in 2001 . Meteorological conditions are as follows. Air temperature was $26.8^{\circ} \mathrm{C}$. Solar radiation was 437 $\mathrm{Wm}^{-2}$. Relative humidity was $94 \%$. Wind speed was $0.7 \mathrm{~ms}^{-1}$ (height $2 \mathrm{~m}$ ).

の影響により, 蒸散速度に差が表れたあのと推察した。

\section{4 窒素施用量の異なる水稲の生育と葉身中のクロ ロフィル濃度の推移}

葉身中のクロロフィル濃度に差をつけるために，施肥 量を大幅に変化させ栽培した 2000 年圃場実験での生育 の推移を Fig. 5 に示した。地上部乾物重の推移をみる と（Fig. 5A)，N13 区が他の処理区と比較して最も大 きく推移した。N13 区の乾物増加速度は, 追肥後（201 日：1月 1 日を起点とした日数）加ら出穗期（224 日）に 加て増加速度が大きく, 出穂後増加速度は緩やかに なった。ほかの処理区も同様の傾向を示した。葉面積指 数（Fig. 5B）むN13 区が生育期間中最も大きく推移 し, 出穂期に最大で 6.1 に達した。 $\mathrm{N} 9$ 区の最大值は 4.9, N4区は3.0, N0区は 2.4であった。

Fig. 6 には, 葉身中のクロロフィル濃度の変化を示し た。上位展開第 1 葉 (Fig. 6A) では, すべての処理区で 生育初期のクロロフィル濃度が最む高く, 生育が進むに つれて低下した。穎花分化期の追肥により, 濃度が高 まったが，再び濃度は低下する傾向がみられた。第 2 葉 (Fig. 6B), 第 3 葉 (Fig. 6C) についても，ほぼ同様の 変化を示した。Inada（1994）は, 埼玉県下において水稲 の上位展開第 2 葉の葉色変化を葉緑素計（KI-1）で調 


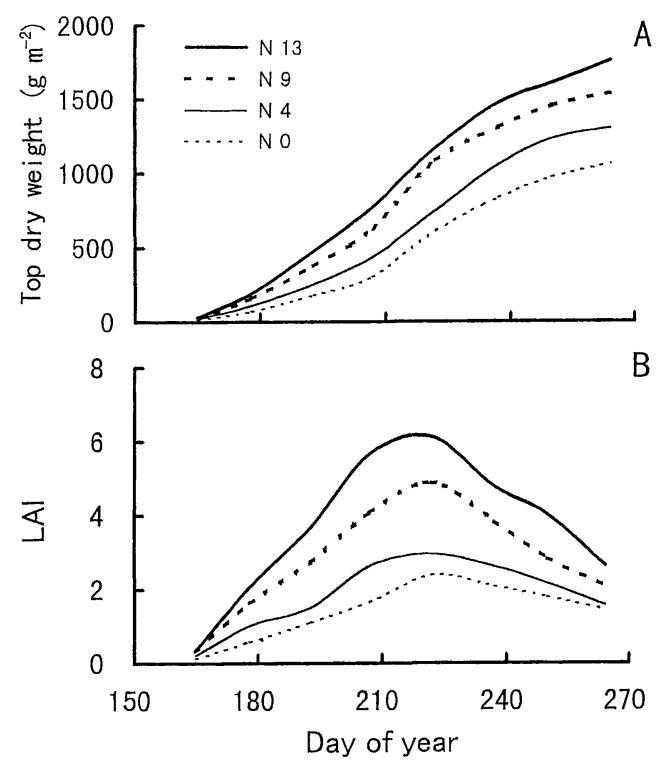

Fig. 5. Changes in top dry weight (A) and LAI (B) for field experiment in 2000.

ベた。葉色値は, 移植して活着後から高くなり（クロロ フィル濃度は高くなる）生育期間中最む高い值を示した 後低下すること，しかし穎花分化期の追肥によって葉色 值は再び高まり出穂期にピークを示し, 出穗 1 力月後を 境に急激に低下することを報告している。 Miyama et al. (1984) は，千葉県下に打いて移植後 1 力月から出穂 期まで, 水稲群落の葉色の变化を葉色板で調べた。生育 初期葉色示度は高い（クロロフィル濃度は高い）が，生 育が進むにつれ低下すること, 幼穂形成期の追肥により 葉色示度は高まり出穂前にピークに達したのち, 低下す ることを報告している。今回の実験でも，これらの報告 とほぼ同様のクロロフィル濃度の変化がみられた。

クロロフィル濃度は当然のことながら施肥量に左右さ れる。上位展開第 1 葉の各処理区に打けるクロロフィル 濃度の推移をみると（Fig. 6A)，N13 区が生育期間中, 他の処理区に比べて, 最む高く推移する傾向がみられ, 次に N9 区, N4区，N0区と N0区で最むクロロフィル 濃度が低い傾向にあった。第 2 葉 (Fig. 6B), 第 3 葉 (Fig. 6C) についてあ同様の傾向がみられた。

続いて, N13 区の上位 3 葉間のクロロフィル濃度を 比較すると, 出穂直後までは, 上位展開第 1 葉（Fig. 6 A）が第 2 葉 (Fig. 6B), 第 3葉 (Fig. 6C) に比べて

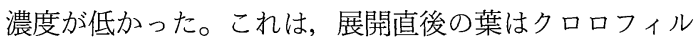
濃度が低く，活動中心葉になる時期に最あ濃度が高くな るためであると考えられた。出穂後, 展開する葉はない ために，出穂期加ら 2 週以降（240日）は，最も早く展

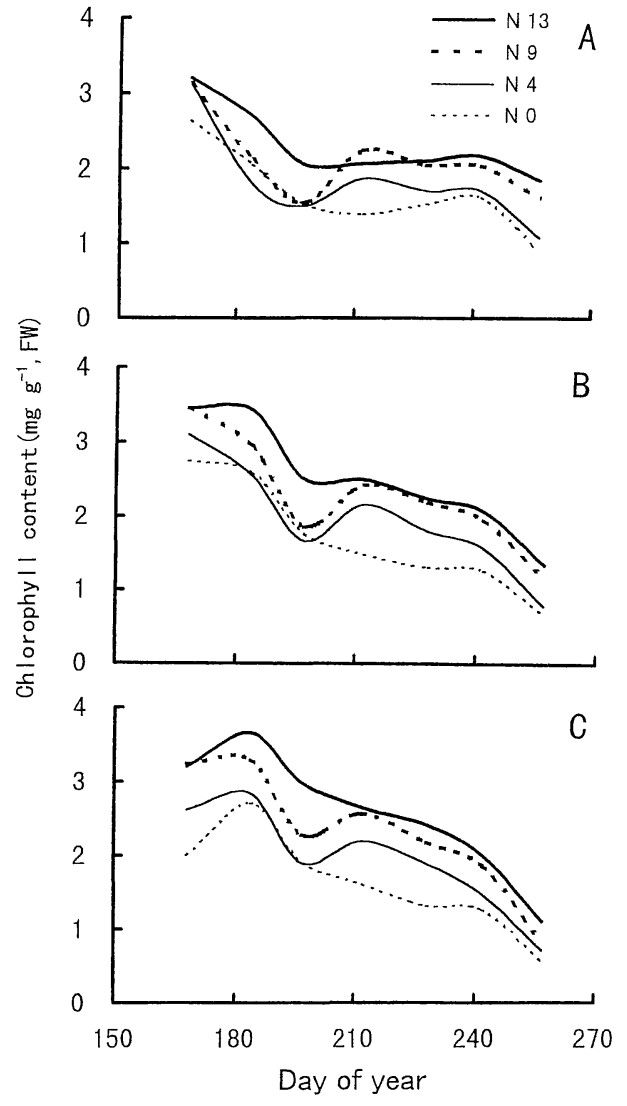

Fig. 6. Changes in chlorophyll content in the first upper leaf (A), the second upper leaf (B) and the third upper leaf (C) for field experiment in 2000 .

開した上位第 3 葉で老化が進みクロロフィル濃度が低下 し, 逆に展開の最も遅加た止葉は登熟後期まで第 2 葉, 第 3 葉に比べてクロロフィル濃度は高く保たれた。 他の処理区でも同じ傾向がみられ，この結果は Furuya （1987）の報告と同様のあのであった。

2000 年圃場実験では, 処理区間のクロロフィル濃度 差が生じるように施肥量を大幅に増加させたが，その効 果は十分に現れた。

\section{5 SPAD 值の異なる葉の葉気温差の日変化}

SPAD 值の異なる葉の葉気温差の日変化をみるため に，2000 年圃場実験で 8 月 28 日に得られたデー夕を用 い解析した。Fig. 7 に, 測定日の気象条件の推移を示し た。測定日の天候は晴天であったが，日射強度（Fig. 7 A）は雲の影響により変動が大きく, 日量は 17.3 $\mathrm{MJm}^{-2}$ であった。気温（Fig. 7 B）は, 午前中から徐々 に上昇し，13: 40 に最高気温 $32.4^{\circ} \mathrm{C}$ を示した。飽差 


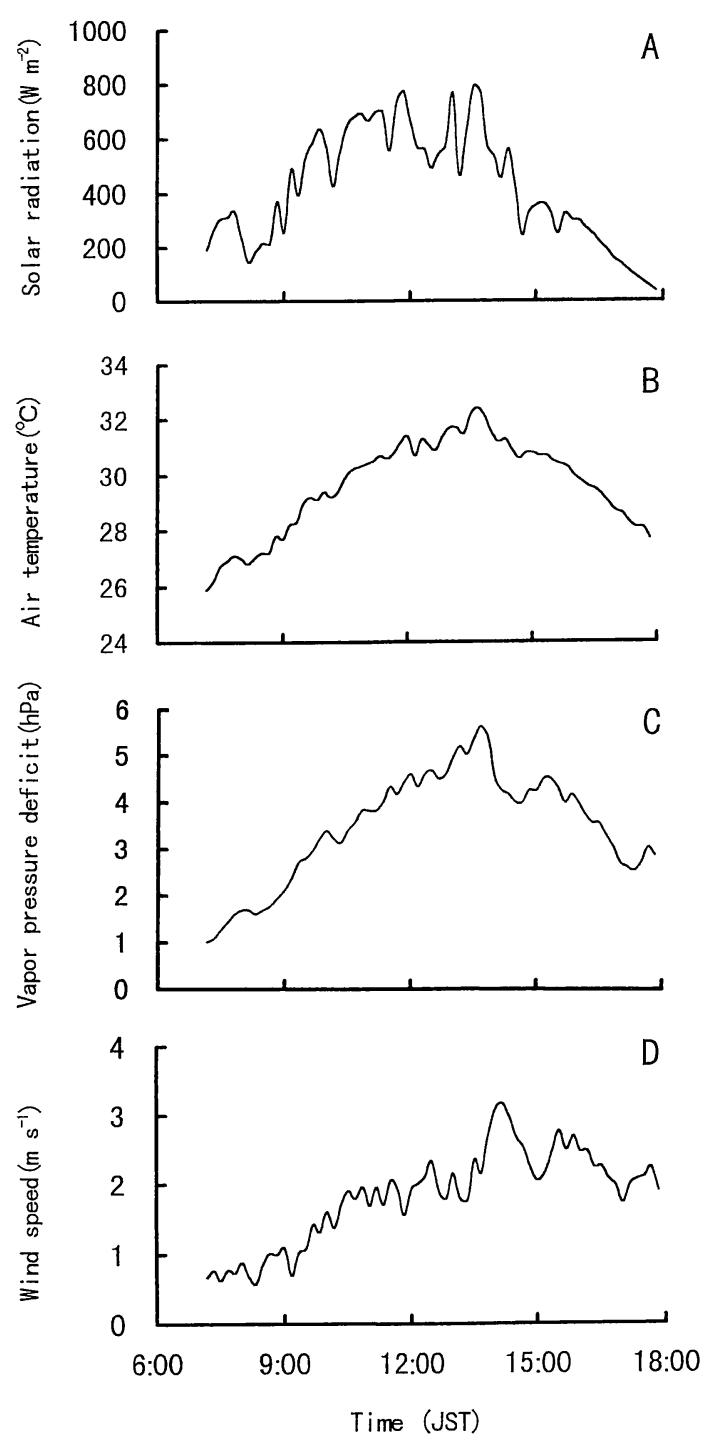

Fig. 7. Diurnal variations in meteorological conditions, solar radiation (A), air temperature (B), vapor pressure deficit (C), and wind speed (D) on 28 August in 2000 .

（Fig. 7C） あ午前中から大きくなり，13: 40 に最大値 に達し, $5.6 \mathrm{hPa}$ を示した。風速（Fig. 7D）は 9 時まで は $1 \mathrm{~ms}^{-1}$ 以下であったが，以後徐々に大きくなり 14 : 10 には最大 $3.2 \mathrm{~m}^{\mathrm{s}-1}$ に達した。風速は, 午前中に比べ 午後の方が大きく推移した。

Fig. 8 には, SPAD 值の異なる止葉の葉気温差の日 変化を示した。SPAD 值は前日の 8 月 27 日に測定され たあのである。SPAD 值 26.1 の止葉の葉気温差は, 日 中の 7 時から 14 時までは, ほぼプラスで葉温が気温に

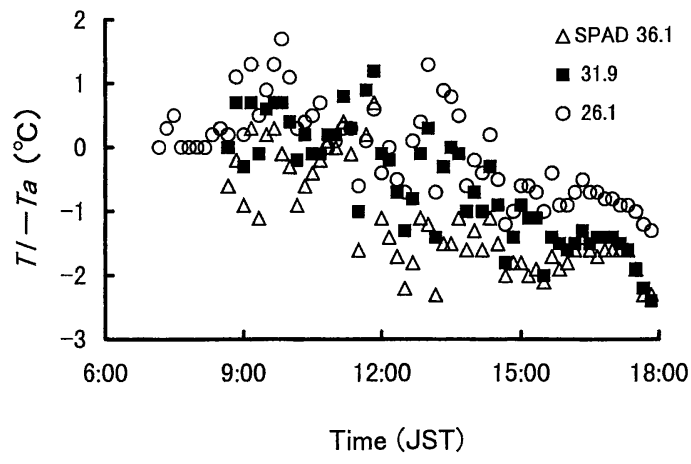

Fig. 8. Diurnal Variations in Leaf temperature and air temperature difference $(T l-T a)$ for different SPAD value leaf on 28 August in 2000.

比べて高く推移する傾向にあった。10 時に葉気温差は

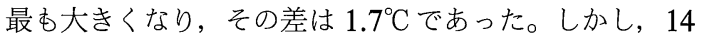
時以降葉温は気温に比べて低くなった。SPAD 值 31.9 の止葉をみると, 午前中葉気温差はプラスで推移し,

SPAD 值 26.1 の止葉に比べてその差は小さい傾向がみ られた。午後, 葉気温差はマイナス, すなわち葉温は気 温に比べて低くなり, 夕刻に近づくにつれ葉温は気温に 比べて徐々に低くなった。SPAD 值 36.1 の止葉は, 日 中葉気温差はほとんどマイナスで推移し，13:10 に葉 温は気温に比べて最も低くなり, 葉気温差は $-2.3^{\circ} \mathrm{C} て ゙$ あった。以上 3 葉の日中の葉温を比べると，ほぼ SPAD 值 26.1>31.9>36.1 の順に高かった。

一般に気孔抵抗に影響を及ぼす要因として, 日射, 湿 度, 二酸化炭素濃度, 作物体内の水分状態があげられる。 しかし, 水稲の場合, 通常の嘎場環境下では主に日射, 湿度による影響が大きい（Ishihara et al., 1971; Inoue et al., 1984)。また, 葉面からの蒸散については, 気孔抵 抗, 葉面境界層の抵抗, 日射, 湿度, 葉温, 気温, 風速 が関与する。葉温は葉へ入射するエネルギーが，上記の 蒸散すなわち潜熱, 顕熱, 葉からの赤外放射に分配され ることにより成立する。葉温の成立に対しては，上記の 要因が関わっているが，今回はこれら複数の要因が複雑 に絡んでいるため, 特に個々の要因と葉温の関係につい て解析は行わなかった。ただし, SPAD 值と蒸散抵抗, 蒸散速度の関係を 3.3 で述べたように, 気孔開度に影響 を及ぼす葉身中のクロロフィル濃度が，大きい要因の 1 つと考元られた。

Table 4 には 2000 年 8 月 28 日における各時刻の葉 気温差と SPAD 值の単相関係数を示した。午前中は一 $0.45 \sim-0.52$ 之中位の相関係数であったが, 午後両者の 相関は高まり, 13 時では $-0.49,14$ 時では $-0.62,15$ 時では -0.80 , と 15 時に最も高い相関を示した。しか 
Table 4. Coefficients of correlation between leaf temperature and air temperature difference $(T l-T a)$ and SPAD value at different times on 28 August in 2000.

\begin{tabular}{cc}
\hline Time & Coefficient of correlation \\
\hline $9: 00 \sim 9: 10$ & -0.52 \\
$10: 00 \sim 10: 10$ & -0.45 \\
$11: 00 \sim 11: 10$ & -0.48 \\
$12: 00 \sim 12: 10$ & -0.47 \\
$13: 00 \sim 13: 10$ & -0.49 \\
$14: 00 \sim 14: 10$ & -0.62 \\
$15: 00 \sim 15: 10$ & -0.80 \\
$16: 00 \sim 16: 10$ & -0.73 \\
$17: 00 \sim 17: 10$ & -0.64 \\
\hline
\end{tabular}

し夕刻に近づくつれ再び相関係数は低下し，16 時では $-0.73 ， 17$ 時では， -0.64 であった。SPAD 值による 葉温の変動範囲を推定するために，それぞれの時刻にお ける葉温の最大值と最小値の差を SPAD 值と葉気温差 の回帰式により求めたところ，9: 00 では $0.83^{\circ} \mathrm{C} ， 12$ : 00 では $1.36^{\circ} \mathrm{C}, 15: 00$ では $1.80^{\circ} \mathrm{C}$ に達した。このよう に SPAD 值により $0.83 \sim 1.80^{\circ} \mathrm{C}$ の最高葉温と最低葉 温の差がみられた。Fig. 9 には 8 時 40 分から 17 時 40 分までの葉気温差の平均値と SPAD 值の関係を示し た。両者の相関係数は， -0.72 と日中の決まった時刻だ けでなく，日中の平均葉気温差においてむSPAD 值と 高い相関を示すことが確かめられた。

\section{6 群落表面温度と気温の差とクロロフィル濃度の 関係}

Table 5 には，サーモグラフィーを用いて，2000 年 8 月 29 日 11: 43〜11: 49 に測定した各処理区の群落表 面温度と気温の差を示した。展開した上位 3 葉の葉身中 クロロフィル濃度は，3.4で述べたように，施肥量の多 い N13 区で最む高く，次に N9 区，N4 区，N0 区と N 0 区は最も低かった。群落表面温度と気温の差は，N13 区で $0.01^{\circ} \mathrm{C}, \mathrm{N} 9$ 区で $0.37^{\circ} \mathrm{C}, \mathrm{N} 4$ 区で $0.50^{\circ} \mathrm{C}, \mathrm{N} 0$ 区 で $0.86^{\circ} \mathrm{C}$ とクロロフィル濃度の高い処理区ほど，群落 表面温度之気温の差は小さく, 逆にクロロフィル濃度の 低い処理区で両者の差は大きかった。N0 区之 N13 区 の群落表面温度の差は $0.85^{\circ} \mathrm{C}$ であった。この結果より， 熱赤外リモートセンシングは, クロロフィル濃度の異な る群落間の群落表面温度差を検出できるあのと考えられ た。さらに，固場内に抢ける相対的なクロロフィル濃度 差の検出の可能性が示唆されることから，熱赤外リモー トセンシング情報は，圃場での窒素肥料の施用むらの検 出など，肥培管理に利用できるのではないかと考えられ た。

ただし，今回の実験では施肥量を大幅に増加させ，各

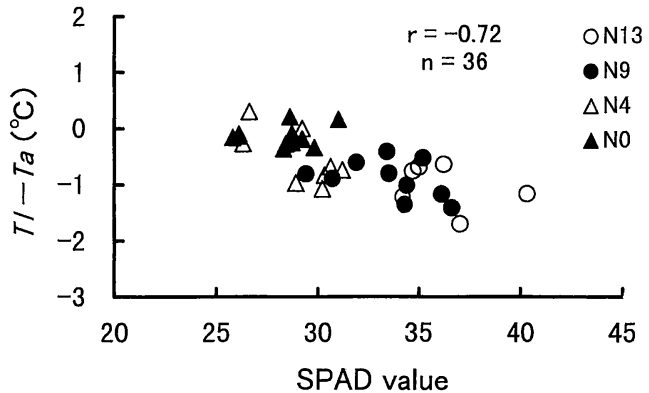

Fig. 9. Relationship between SPAD value and diurnal mean difference between Leaf temperature and air temperature $(T l-T a)$ on 28 August in 2000.

Table 5. Difference between Canopy temperature of paddy rice community and air temperature.

\begin{tabular}{cc}
\hline Experimental treatment & $\begin{array}{c}\text { Canopy temp.-Air temp. } \\
\left({ }^{\circ} \mathrm{C}\right)\end{array}$ \\
\hline N13 & $0.01 \pm 0.46$ \\
N9 & $0.37 \pm 0.39$ \\
N4 & $0.50 \pm 0.41$ \\
N0 & $0.86 \pm 0.59$ \\
\hline
\end{tabular}

Measurement was conducted from $11: 43$ to $11: 49$ on 29 August in 2000. Meteorological conditions are as follows. Air temperature was $30.3^{\circ} \mathrm{C}$. Relative humidity was $61 \%$. Solar radiation was $651 \mathrm{Wm}^{-2}$. Wind speed was $1.1 \mathrm{~ms}^{-1}$ (height $2 \mathrm{~m}$ ). Figures are the mean \pm standard deviation.

処理区間での群落表面温度差および SPAD 值の異なる 止葉間の葉温差を検出したこと，また群落内でのクロロ フィル濃度の分布と群落表面温度との関係については検 討しなかった。これらの点については，窒素施用量を実 際に行われている農家の施用量と同量に設定した圃場内 で，クロロフィル濃度の分布と群落表面温度との関係を 調べる必要がある。このほかに, Table 4 に示したよう に, SPAD 值と葉気温差の相関係数が測定時刻によっ て異なることから，固場内に抢いて相対的なクロロフィ ル濃度分布を検出するために，最む適した気象条件を知 る必要がある。今回，葉身中のクロロフィル濃度が気孔 開度に影響を及ぼしていると考えられたので，この関係 を含めて水稲群落表面温度および葉温の成立について検 討する必要があると考えられた。

\section{7 群落表面温度と気温の差と 1 穂籾数, 収量との} 関係

ところで, 1998 年ポット実験では上位 3 葉の平均 SPAD 值の高い穂で, 1999 年圃場実験では止葉の葉温 
の低い穂で 1 穂籾数抢よび 1 穂籾重が大きかった。この ことから, 群落表面温度および葉温情報が収量構成要素 および収量の推定に利用できるのではないかと考えた。 2000 年圃場実験の各処理区の粐収量をみると，N13 区 が $803 \mathrm{gm}^{-2}$, N9 区は $716 \mathrm{gm}^{-2}, \mathrm{~N} 4$ 区は $551 \mathrm{gm}^{-2}, \mathrm{~N}$ 0 区は $458 \mathrm{gm}^{-2}$ と $\mathrm{N} 13>\mathrm{N} 9>\mathrm{N} 4>\mathrm{N} 0$ の順に高かっ た。各処理区の収量構成要素をみると, 1 穂粐数は $\mathrm{N}$ 13 区が 72 粒，N9 区が 74 粒，N4 区が 80 粒，N0 区が 72 粒と, 1 穂粐数に及ぼす窒素施用量の影響はみられな かった。1 平方メートル当たりの穂数は，N13 区が 462 本，N9 区が 370 本，N4 区が 299 本，N0 区が 250 本 と $\mathrm{N} 13>\mathrm{N} 9>\mathrm{N} 4>\mathrm{N} 0$ の順に多く, 粐収量が窒素施用 量の多い処理区で大きかったのは，穂数が多かったため であった。1998 年ポット実験および 1999 年圃場実験 で得られた，葉身中のクロロフィル濃度の高い穂で粐数 が多い，という同様の結果は得られなかった。この原因 は，追肥を行わなかった 1998 年ポット実験で SPAD 值と 1 穂粐数の相関が高かったこと，1999 年圃場実験 の無追肥区においても SPAD 值と 1 穂籾重の相関が高 かったことから，追肥の時期が適切ではなかったためと 考えられた。一般に，幼穂分化期から穎花分化期中期 （およそ出穂 19 32 日前）に加けての追肥は， 1 穂籾数 の増加につながることが知られている。1999 年戋場実 験では出穂 22 日前, 2000 年圃場実験では出穗 23 日前 に追肥を行った。 1 穂籾数の増加につながる時期の施肥 であったが，やや遅かったため追肥の効果が十分に現れ なかったのではないかと考えられた。

\section{4. まとめ}

水稲群落の葉色と群落表面温度および葉温との関係を 調べるために, 1998 年はポット実験, 1999 年, 2000 年 は圈場において窒素施用量を変え栽培し, サーモグラ フィーを用いた群落表面温度, 熱電対を用いた葉温の測 定を行った。その結果，以下のことが明らかになった。

（1） 1999 年圃場実験で，サーモグラフィーを用い登 熟期の群落表面温度を測定したところ, 追肥区は無追肥 区に比べ群落表面温度が低かった。

（2）続いて熱電対を用いて，測定した葉気温差と葉緑 素計による SPAD 值の関係を調べた。その結果, 両者 の間に高い負の相関がみられ, SPAD 值の高い葉で葉 温が低く, SPAD 值の低い葉で葉温が高かった。また, 1998 年ポット実験では 1 穂籾数と出穂直前の上位 3 葉 の平均 SPAD 值との間に高い正の相関がみられ，1 穂 粐重もSPAD 值の高い穂で大きかった。1999 年圃場実 験でも, 葉温の低いすなわち SPAD 值の高い止葉の 1 穂籾重は大きかった。
（3） 2001 年のポロメー夕による蒸散抵抗，蒸散速度 の測定では, SPAD 值の高い葉ほど蒸散抵抗が小さく, 蒸散速度は大きかった。蒸散抵抗と SPAD 值および蒸 散速度と SPAD 值の関係は，いずれも高い相関を示し た。このことから，SPAD 值の高い葉は，蒸散速度が大 きかったために，潜熱が奪われ，葉温が低かったものと 考えられた。

（4） 2000 年围場実験は，処理区間の葉身中のクロロ フィル濃度に差をつけるために, 窒素施用量を大幅に増 加させ行った。サーモグラフィーを用いた群落表面温度 および熱電対による葉温測定を行ったところ，1999 年 圃場実験と同様に葉身中のクロロフィル濃度の高い処理 区ほど群落表面温度は低く，SPAD 值の高い止葉で葉 温の低い結果が得られた。1998 年ポット実験および 1999 年圃場実験で， 1 穂粐数の推定に熱赤外リモート センシング情報が利用できるのではないかと考えられた が, 2000 年固場実験では, クロロフィル濃度の高い処理 区で 1 穗籾数が多いという結果は得られなかった。

（5）以上のことから，熱赤外リモートセンシング情報 を用いて水稲群落間の相対的なクロロフィル濃度差の検 出が可能であることが確認できた。熱赤外リモートセン シング情報は，固場における肥料むらの検出など肥培管 理に利用できるのではないかと考えられた。

\section{謝 辞}

本研究での生育調査, 収量調査等では, 中央農業総合 研究センター業務第 1 科冨板美明氏をはじめ業務科職 員の方々には, ご協力を得ました。また, 研究の遂行で は当センター井上君夫気象立地研究室室長並びに中園江 研究員にはご配慮を頂きました。ここに記して各氏に謝 意を表します。

\section{References}

Arnon, D. I., 1949: Copper enzymes in isolated chloroplasts. Polyphenoloxidase in Beta vulgaris. Plant Physiol., 24, 1-15.

Furuya, S., 1987: Growth diagnosis of rice plants by means of leaf color. JARQ, 20, 147-153.

Homma, K., Nakagawa, H., Horie, T., Ohnishi, H., Kim, H. Y. and Ohnishi, M., 1999: Energy budget and transpiration characteristics of rice grown under elevated $\mathrm{CO}_{2}$ and high temperature conditions as determined by remotely sensed canopy temperatures. Jpn. J. Crop Sci., 68, 137-145.

Inada, K., 1994: Measurement of leaf color on crop. 7. Measurement of leaf color and application to management of crop growth and nutrition. Agr. Hort., 69, 389-394（稲田勝美, 1994: 緑を測る. 7. 
葉色の測定とその栄養・生育診断への利用. 農業およ び園芸，69，389-394）.

Inoue, K., Sakuratani, T. and Uchijima, Z., 1984: Stomatal resistance of rice leaves as influenced by radiation intensity and air humidity. J. Agric. Meteorol., 40, 235-242.

Inoue, Y., 1986: Remote-monitoring of function and State of crop community. I. Analysis of thermal image of crop canopy. Jpn. J. Crop Sci., 55, 261268.

Inoue, Y., 1987: Remote-monitoring of the physiological-ecological status of crops. IV. Quantitative relationship between photosynthetic rate and transpiration rate per vapor pressure deficit for corn and soybean under field conditions. Jpn. J. Crop Sci., 56, 474-481.

Ishihara, K., Ishida, Y. and Ogura, T., 1971: The relationship between environmental factors and behaviour of stomata in the rice plant. 2. On the diurnal movement of the stomata. Jpn. J. Crop Sci., 40, 497-504.

Ishihara, K., Ebara, H., Hirasawa, T. and Ogura, T., 1978: The relationship between environmental factors and behaviour of stomata in the rice plants. VII. The relation between nitrogen content in leaf blades and stomatal aperture. Jpn. J. Crop Sci., 47, 664-673.

Ishihara, K., Sago, R., Ogura, T., Ushijima, T. and Tazaki, T., 1972: The relationship between environmental factors and behaviour of stomata in the rice plant. 4 . The relation between stomatal aperture and photosynthetic rate. Jpn. J. Crop Sci., 41, 93-101.

Jackson, R.D., Idso, S. B., Reginato, R.J. and Pinter, P.J. Jr., 1981: Canopy temperature as a crop water stress indicator. Water Resour. Res., 17, 1133-1138.

Kumura, A., 1956: Studies on the effect of internal nitrogen concentration of rice plant on the constitutional factor of yield. Jpn. J. Crop Sci., 24, 177180.

Miyama, M., Katsukida, H. and Saito, K., 1984: Growth diagnosis of rice plants based on leaf green scores by color scale. Agr. Hort., 59, 775-781（深山 政治・勝木田博人・斉藤研二, 1984: 葉色票による水 稲の生育診断, 農業扔よび園芸, 59, 775-781).

Miyashita, K., Maitani, T. and Takeda, K., 1999: Comparison of surface temperatures of barley varieties under high temperature conditions. $J$. Agric. Meteorol., 55, 323-328.

Pinter, P. J. Jr., Stanghellini, M.E., Reginate, R. J., Idso, S. B., Jenkins, A.D. and Jackson, R.D., 1979: Remote detection of biological stresses in plants with infrared thermometry. Science, 205, 585-587.

Tsuno, Y., Yamaguchi, T., Omoji, O. and Kai, K., 1991: Relation between the leaf color of rice and the stomatal aperture shown by the infiltration method with special reference to the climatic conditions. Jpn. J. Crop Sci., 60, 475-483.

Wada, G. and Matushima, S., 1962: Analysis of yield-determining process and its application to yield prediction and culture improvement of lowland rice. L XIII. On the mechanism of determining the number of spikelets. Jpn. J. Crop Sci., 31, 23-26.

Yamamoto, H., Suzuki, Y., Iwano, M. and Hayakawa, S., 1995: Remote sensing of occurrence place of rice blast disease by infrared thermal image. Jpn. J. Crop Sci., 64, 467-474. 